\title{
Philosophy with Children: A Rights-based Approach to Deliberative Participation
}

Claire Cassidy

School of Education, University of Strathclyde, Glasgow, Scotland

\section{Abstract}

In advancing children's rights, and human rights more broadly, this article supports the view that participation through deliberation by children is desirable. Practising Philosophy with Children, through an approach such as Community of Philosophical Inquiry, is proposed as a powerful way forward as a rights-based means of supporting children to deliberate about matters affecting them in society. In considering that children are educated about, through and for rights, an example of children's philosophical dialogue is provided to illustrate children deliberating on rights issues, and how teachers might use such dialogue to influence their teaching in this area. The suggestion is that participating in practical philosophy enables children to practise human rights behaviour as means of participating beyond consultation exercises and as an approach to facilitating their engagement with ideas and issues that are important to the promotion of rights for all.

Keywords: Rights-based approach; participation; deliberation; dialogue; Philosophy with Children; children's voice 


\section{Introduction}

In advancing children's rights, and human rights more broadly, it could be argued that participation through deliberation is desirable. Such deliberation is vital in the exploration of the 'plurality of ideas and beliefs, where values and assumptions can be challenged' (Cassidy, 2016, p.511) in the pursuit of a healthy democracy. It is in democracies that human rights are more likely to be respected and flourish, but it is not in all democracies that children have opportunities to engage in deliberative participation. The United Nations Convention on the Rights of the Child (UNCRC) (United Nations, 1989) clearly articulates, under Article 12, that all children are entitled to express their views in matters concerning them. Of course, there is a challenge in determining matters that do not concern or affect children; the likes of war, decisions about the economy, climate change, and so on, have a direct bearing on the lives of children (Cassidy, 2016). Children are, as Biesta et al. (2009) say, 'part of the social fabric' (p.20) to which we all belong.

Children inhabit the world, matters that impact upon adults also concern children, and children's participation ought to be facilitated. As MacNaughton et al. (2007) highlight, when discussing the United Nations' General Comment No.7 on children's rights, young children, and those who are older, are social actors, able to 'create and communicate valid views about the social world' (p.164). Much has been written about how children might engage in democratic processes or systems, primarily in school contexts (Westheimer \& Kahne, 2004; Gündoğdu \& Yildirim, 2010; Bron \& Thijs, 2011). Elsewhere there is the suggestion that doing Philosophy with Children (PwC) might lead to living well (Cassidy, 2012a) and that PwC might also be an approach to support children in furthering human rights (Cassidy, 2016). In light of Lundy's (2007) assertion that 'voice is not enough' and that space, audience and influence also demand consideration, ways must be found to advance beyond where we are at present. Certainly, in the twenty-five years since the first issue of this journal, much has been done to advance children's rights in terms of legislation and in education. The way 
forward, though, ought to address ways in which children might be more fully included as members of society, who think carefully about rights issues as a way of enacting rights.

The present article aims to propose a way forward by illustrating how doing practical philosophy might be seen as a rights-based means of supporting children to deliberate about matters affecting them in society. This deliberative participation will be evidenced through an example from children's philosophical dialogue.

\section{A way of life}

'The best way,' asserts Gündoğdu and Yildirim (2010), 'to safeguard and perpetuate democracy and human rights is to educate people at an early age to be democratic and to respect the rights of other people' (p.525). This is in accord with Gregg (2016) who, in advocating a state where human rights is situated at the core, proposes that 'better civic-educated citizens are better able to persuade others to participate in human rights politics' (p.130), and that this will require independent thinkers. In Dewey's 1916 Democracy and Education, he makes it clear that democracy is a way of life, but it is important that individuals are able to learn and practise this way of life if they are to be good at it. Since it is important that children are 'involved in social life and society' (Bartels et al., 2016, p.681), if we are to advance democracy and human rights, then it is important that they learn a way of life that will support that goal. The approach advocated by Struthers (2015) is that they learn through, about and for human rights. In learning through human rights, teachers take an approach that is rights-based; it is respectful and democratic and affords children their views. At the same time, children learn about human rights, partly as a consequence of the modelling of the rights-based approach in learning through human rights, but they also need to be taught what rights are and what it means for these to be breached. Ultimately, the argument would run, this, in turn, leads to children being educated to enact human rights in their lives. PwC might be one approach that supports this model. 


\section{Philosophy with Children as a human rights process}

In the USA in the 1970s, concerned by the lack of critical thinking evidenced by the young people in his country at a time of great uncertainty, Matthew Lipman developed a practice called Philosophy for Children (P4C) (Lipman, 2003; McCall, 2009). To that end, as a professor of philosophy, he developed a programme that introduced young people to philosophical thinking and reasoning. Since then, several approaches to doing Philosophy with Children (PwC) have evolved from Lipman's original programme. What the different practices have in common is that rather than being focused on academic philosophy where individuals learn about the ideas of others (Gazzard, 1996; Murris, 2000), they engage in philosophical dialogue in a more or less structured format, and the content of the dialogue is driven by the participants' own ideas and thinking. The focus in this article will be on one specific practice: McCall's Community of Philosophical Inquiry (CoPI) (McCall, 1991, 2009; Cassidy, 2007, 2012b; Cassidy \& Christie, 2014).

McCall worked with Lipman in the early 1990s and her approach to CoPI grew out of that work (McCall, 2009). While there are some features in common with the other PwC practices, CoPI is distinct in that it is practised with people of any age, from three years-old upwards, without any adaptation to its format (Cassidy \& Christie, 2014). Indeed, with respect to the constant structure, and its accessibility to all, the very form of CoPI is rights-focused. Age and academic ability are no bar to participation. CoPI adheres to the following structure and associated rules. Each element, in its own way, supports the claim to it being a rights-based approach, but the practice should be taken as a whole, which may make the claim to it being facilitative of rights all the stronger.

\section{Structure, rules and supporting dialogue}

At the very outset of a session participants sit in a circle. They are so positioned in order that they can see one another easily and, importantly, in being seated equidistantly, no one person is set apart as an authority figure or as someone excluded from the group (Cassidy, 2007). All participants hold 
an equal place in the group - or community, as it is called. The facilitator, however, remains outside the circle. While she has the role of ensuring the rules are followed, she does not contribute to the content of the dialogue. The facilitator's role is one that strives to ensure the dialogue is as philosophical as possible and interventions are made only to seek clarification. The dialogue belongs to the participants and they determine which ideas are pursued and which are not by following one line of argument or another - or even several at the same time. All contributions are important and valued since each builds on previous ones.

Once seated, the session begins with a stimulus, usually a written stimulus in the form of a newspaper article, poem, short story or extract from a longer text that has philosophical potential. The participants take it in turn to read the stimulus aloud, going round the circle, with participants reading as much or as little as they are comfortable with. If they do not want to read aloud they can pass, and if they cannot read aloud - children or adults - the facilitator will read the text to them. The stimulus is an important shared experience for the community; no-one comes to the session with any more or less information than anyone else in terms of what will be presented. Similarly, in reading aloud, the participants share the experience of the text, thereby allowing them to hear their voices in the group (Cassidy, 2007). Sometimes, with participants who are not fluent readers, the facilitator will distribute the stimulus and read aloud with the participants reading half a beat behind her in order that they have the shared experience and are also able to hear their voices in the space.

Following the reading, participants are asked for questions or puzzles arising from the text or that occur to them during the reading. Unlike some PwC approaches, the questions are generated by the participants rather than these being imposed. It is important that the participants offer questions as these will afford them ownership of the questions, and they will be more invested in addressing questions of their own devising. The facilitator records the questions exactly as they are asked, no corrections are made and no interpretation is given to the questions. It is important that the question is captured accurately since only the questioner knows what is intended by it; it is not the 
place of the facilitator or other participants to reframe the question as it is recorded (Cassidy, 2012b). The facilitator selects the question into which the participants will inquire with her task being to ensure the best dialogue possible in order that the participants' philosophical thinking is extended. It may seem that the facilitator selecting the question and enforcing the rules goes against a rights-based or democratic approach. However, as the facilitator is the person with the background in academic philosophy, she should be most able to recognise the question with the strongest philosophical potential. Furthermore, democracies are not laissez-faire, they require structures in order to function well and it should be clear when certain structures or rules are facilitative. Indeed, CoPI is a good example of the way in which such structures may be supportive.

After selecting a question, the facilitator asks the participant who posed the question to begin addressing the question. There are rules the participants have to follow thereafter. They must raise their hand to indicate that they have something they wish to contribute. The facilitator will select the speaker, but participants will not necessarily be called in the order in which they raised their hand. Again, rather than this rule working against a positive ethos, as the facilitator is seeking to juxtapose speakers' perspectives to ensure a forward momentum in the dialogue, she is working for the benefit of the participants' dialogue and at no point interposes questions of her own. It should also be noted that everyone who wishes to speak will have the opportunity to do so. At the same time, it is important to be clear that participants who do not volunteer to speak are not made to. The participant retains the power to speak or not within the session, though there is evidence of previously shy, quiet, or children who are marginalised volunteering to speak in the CoPI context when they would not in other classroom settings (Cassidy et al., under review). Indeed, Robinson (2011) makes clear that the power teachers generally hold in the classroom challenge the effective implementation of Article 12.

When participants speak they must begin by agreeing and/or disagreeing with at least one previous statement. The need to make a connection to a previous contribution necessitates that participants 
listen carefully to one another in order to build on the ideas shared, an activity, where participants are learning through human rights by adopting respectful behaviour. Not only must the participants agree/disagree, they have to provide reasons for that agreement/disagreement. Reason-giving, or providing justifications for views held or expressed is vital in the promotion of effective citizenship and rights (McCall, 1991; Gazzard, 1996; Lunenberg \& Korthagen, 2009). It is not sufficient to make a point or declare a point; consideration is required. What is significant in CoPI is that participants need not present their own personally held opinions, while also presuming that everything is open to question. It is important that participants are able to experiment with ideas and are able to see the various sides of an argument. In a democracy, a variety of perspectives is important, but they must also be able to be challenged and justified. In CoPI no topic is out of bounds and all views can be aired. It is understandable that there may be some anxiety that participants share and are persuaded to ideas that are, say, racist or homophobic or sexist. It is important that such views are aired in order that they can be argued against; and because the reasoning is under scrutiny, the weaknesses in the arguments are exposed and should be countered. Of course, it would be irresponsible of the facilitator, usually the class teacher, to allow the comments to go unchallenged or to be adopted by the participants, but it is important that she does not interfere in the dialogue or participants will think that some views should not be shared openly, and they, therefore, fail to explore certain topics. Under such circumstances, the teacher as soon after the CoPI session as possible, should directly address the views aired. This is aligned with the notion of learning about rights, while also learning for rights. The fact that there is space for various views to be aired and explored also sees the participants learning through rights.

There are three further rules the participants should follow: they are not permitted to use technical language or jargon; they may not make reference to an authority for their reason-giving; and there is no search for consensus or a conclusion at the end of a session. In order to provide as equal a platform as possible, participants are not permitted to use technical language or jargon in their contributions. This means that everyday language has to be used in order not to exclude others, but 
also because it cannot be guaranteed that everyone would use the terms in the same way (Cassidy, 2007). Therefore, if a participant knows a lot about academic philosophy or computers or football or rights, they should avoid using technical terms. If they do so, they will be asked to explain these terms. It is important to note that in philosophical dialogue words that may be used in everyday conversation may be problematic, so the facilitator would request clarification of such terms, for example, equality, fairness, good, justice or rights.

In addition, because CoPI assumes that everything is open to question, citing an authority such as a TV programme, teacher, book or website for one's agreement or disagreement is not permitted. It is the participants' own reasoning that is important. Finally, in not seeking a conclusion or consensus during or after the session, participants are encouraged to keep thinking about the topic. In drawing conclusions there is the risk that participants consider the topic dealt with and complete; it is important that the dialogue raises questions for the participants over which they wonder after the session has ended. Similarly, a consensus would suggest that the topic is closed and that there is no possibility of further disagreement. Leaving the topic open allows participants to return to it individually, in another context, or even in another CoPI session. Closed-mindedness would not be conducive to a rights-based approach where questioning, reasoning and thinking for oneself are important. It is, therefore, through such dialogue that one may see how children and young people might engage in dialogue about rights.

\section{Rights dialogue}

It is not possible, in the space available, to provide a transcript of several CoPI dialogues, or even a full dialogue. Therefore, in order to illustrate how children engage in philosophical dialogue on rights-based topics, a short extract from one dialogue with a class of fourteen year-olds will be shared. The session follows the same structure and rules as described previously and took place during a Religious and Moral Education class. The session lasted approximately forty-five minutes and the extract, which lasted about ten minutes, is drawn from about ten minutes into the dialogue. 
Bearing in mind that the facilitator selects the order in which participants contribute, her words have been redacted unless they are direct interventions requesting clarification. All participants have been given pseudonyms in the transcript. The participants were discussing the question: In what kind of society would you like to live?

Jason: ... the thing about society is that it's run by money as power and the problem with that is that people with a lot of money don't lose the power at all. People with a lot of money just get even more and more and more. People with a little money start getting less and less and it's because people with big companies don't really get the tax taken off them because of the laws that are in place and the loopholes that are in it.

Rose: I agree with what Jenny said [previously] and what Jason said, that money is power. The eighty-five richest people in the UK make up more than half of all the money that we have right now which is ridiculous given the fact that there is about 6 million people living in London.

Bruce: I agree with Jason and Rose about the laws, but you can't really stop people making as much money because isn't that what part of what democracy is about, allowing people to build themselves up and build themselves up and build themselves up, even though, if they are exploiting like loopholes in the law?

Jason: I kind of disagree with what Bruce said because even though people are allowed to make more money, these people are actually breaking laws to make more money because it is big companies not paying their tax and it's just a giant monopoly of these people that keep getting richer because the law has a giant loophole in it which they can just exploit and take money off poor people so they can get even more money. I know people say it's a democracy so they should be allowed to get richer, yeah, but they shouldn't be allowed to break the law to get richer because the point of the law is to put rules in a country.

Teacher: Can you explain what you mean by a democracy, Jason? 
Jason: A democracy would be something like, that people vote for, I'm not really sure what a democracy is definition wise, but I'm pretty sure it's a government where people vote.

Bruce: Yeah, I get what you're saying but if there is a loophole there and you see an opportunity, you could take it; it's not really breaking the law if there is a loophole in the law. If they directly just didn't pay their taxes, yeah, that would be breaking the law, but say they didn't pay as much tax as they should, that would just be exploiting it, but they would still be paying tax.

Alex: I agree with what Bruce said because, you know how he was saying you are not breaking the law because there is a loophole in it, which is true, and then as well that's not really society's problem, that's just more their problem. It's not our fault that other people are doing something; it would be our fault if all of us were doing it, but it's just certain companies.

Pauline: I agree with what Alex was saying about the tax side of it but, is it not the more money you earn the more tax you have to pay? So, is it not a good thing that they are earning a lot because then the amount they are putting back in is helpful?

Nadia: I disagree with what Jason said earlier because I think it is a bit of a sweeping generalisation saying all big companies have tonnes and tonnes of power and they don't pay tax and all that. There are really big ethical companies in the world that do pay tax and do good things for society. I understand where he's coming from, but there are smaller companies as well who avoid tax and loopholes aren't just in the law so that just big companies find them.

Geri: I disagree with what was said about how large companies have the main input on the way that society is because I wouldn't say that; I would say it's more like as much as they do have an input, I would say it's more people and the way that people act and people are towards each other. I think that's more what society is like, and I get that may have an influence from bigger companies but I don't think that they can really say how we should act towards each other. I think that's just, it's 
caused some of it but I don't think it has anything to do with the way we discriminate against each other.

Teacher: Say a wee bit about what you mean by society.

Geri: I think it's just a group of people that ... I don't know, I think you can get different societies. You can get people who live in one area; a group of people that have the same interests, people who live in different towns and stuff are all a society. I would say a school is a society.

Rose: I disagree with Bruce's point earlier that they should be allowed to make more money which they should be, except you shouldn't be allowed to make so much money that you could afford to lose hundreds of thousands and it would only be a dent; you should be able to make money and then give money back.

Angela: I disagree with what Rose just said, 'you shouldn't be able to make so much money'. If they make the money they've earned it, they've worked hard to make that money and it shouldn't just be taken away from you because they've worked hard for it.

Jason: I disagree with Angela because there are all these companies like Wonga, they have all these closed doors where they say - 'oh we'll give you a loan' but then they actually just take all of your money from you and your income just crushes and then you end up becoming bankrupt because of those companies. I don't think companies should ever be allowed to do that, they are just taking money off of desperate people who don't have much money in the first place, that's why they need a loan, so they are slowly just taking all the money out and then they [the companies] just go and latch on to some other person who is desperate and they just keep repeating. I don't think they should be allowed to take money from poor people, especially ones that are so desperate they have to take out a loan.

Geri: I disagree with Angela as well because, see what she said about these people who worked for their money that were in these big companies, but sometimes they've not, sometimes they could 
have had the company passed on from family members so they've done nothing for the company. They're just earning money, whereas people in Africa work so hard but they get nothing, so I think there should be a line, everyone should get the same amount of money and pay the same.

Jenny: I sort of disagree with Geri's last point where everyone should get the same amount of money. That means people that you said that aren't working but are already making money would get the same amount of money as the person that's working really hard in a different country. I think that the only way to success is if you work hard, and people that don't work hard, you shouldn't have to worry about them, you should worry about yourself and yourself trying to succeed.

Helen: I disagree with Jason's point, I think that even companies like Wonga who take money and it's wrong what they do, but they [Wonga employees] are still trying to make a living for their family. They might be in need but that's not the only option for people so low in money, so people don't need to go to one of those sites, they just go because they're advertised. There are other sites, there are other places like credit unions that are actually ethical so it's not the only place, but Wonga still need to make money, the people who work at Wonga still need to make money for their families.

Teacher: Can you explain a wee bit about what you meant when you used the word 'ethical'?

Helen: Like fair.

\section{What's going on in the dialogue?}

In reading the transcript it is important to look at the role of the teacher. She very rarely intervenes, and when she does so, her questions are concise and clearly focused on key concepts. In picking up on the concepts she does - ethical, democracy, society - she is identifying terms that demand further explanation or exploration. The participants may have chosen to pursue one of the definitions offered to change the focus of the dialogue. For example, Jason was asked to explain 
what he meant by democracy. It would not be uncommon, though it did not happen in this portion of the dialogue, for other participants to agree/disagree with an explanation or definition, thereby leading the dialogue into an inquiry on the nature of democracy. This is important for the teacher to note as Jason's response demonstrates a rather weak or limited conception of democracy. The dialogue is highly illuminative of the children's understanding or grasp of concepts that shape their thinking. This affords the teacher the opportunity of picking up on this through some focused classwork in order that the children are able to develop their conceptual understanding of key ideas such as democracy. Both the direction and content of the dialogue clearly belong to the participants, meaning they retain power in the dialogue, though the teacher's role in identifying terms that are philosophically problematic is important in taking the participants' thinking forward, in the session and outwith it in other lessons.

It is clear that the voices and perspectives being expressed come directly from the participants. Certainly they may be practising views they have heard elsewhere, but they need to work through these for themselves and defend or challenge them, so the thinking must be their own. Of course, it should be said that this is the same for the majority of adults. There are few, if any, fora where children and have the opportunity to discuss their ideas and practise their reasoning. Discussions are usually directed by the teacher with determined learning outcomes towards which the discussion is focused with an end-point in mind.

The transcript illustrates that the views expressed are not all in agreement. There is some disagreement, for example, in relation to responsibility and what constitutes unethical or unlawful behaviour, or whether people should be paid the same amount of money even when they do different jobs, or if people should be allowed to make as much money as possible. While disagreement is crucial for philosophy, it is also a necessary part of life, particularly if human rights are to be addressed. The dialogue illustrates that the disagreements are respectful and focus on the ideas rather than being directed at the person who presented the view. The contributions from 
Rose, Angela and Jason about how much money one should be allowed to make, for example, are clearly in disagreement, but they each respectfully take account of the others' views and use these to advance their argument. In deliberative participation it is important that all perspectives are listened to and challenged in a manner that is respectful. Note, too, that there were elements of the contributions that were not disagreed with entirely, so the young people are able to dissect contributions to support their challenges, thereby also highlighting where there may be possible agreement; which, when trying to advance human rights, is a good place to start. It is clear where there is specific agreement and that the participants build upon others' contributions to make their own. In doing so, they have to pay careful attention so that subtle disagreements/agreements or points to be developed might be forwarded, such as when Bruce says, 'it's not really breaking the law if there is a loophole in the law. If they directly just didn't pay their taxes, yeah, that would be breaking the law'; he is acknowledging the distinction between law-breaking and manoeuvres made to circumvent the law. It is important that the participant picked this up and not the facilitator, it demonstrates that the young people are able to make careful distinctions and develop arguments accordingly.

The dialogue touches on several topics that could be further developed in the classroom context to enhance learning about rights while also learning for rights. The deliberation afforded by the CoPI session allows the participants to raise specific rights or issues related to rights within the dialogue, and that will hopefully influence further thinking, and potentially also positive action (Schertz 2007; Lunenberg \& Korthagen, 2009; Shultz \& Guimaraes-losif's, 2012; Cassidy, 2016). Aside from issues of fair pay, democracy and the merits - or not - of capitalism, the children, through the dialogue, explore ideas around: power; wealth and poverty; ethics and ethical behaviour; cooperation and collectivism; corporations and business; exploitation; charity; personal and social responsibility; and how we ought to live together. Beyond the extract shown, the children returned to many of these themes and interrogated them further. Of course, in the space of one CoPI session they cannot fully address each topic, but there is an interconnectedness of ideas that is important in promoting a 
deliberative space. The ideas are not discrete, nor can they be taught independently of one another. The issues are raised by the children rather than by the teacher; they are making the connections and providing the example, they create the arguments and are engaged in deliberation on the topics they raise.

While the dialogue shows that the young people are able to explore issues or topics they raise themselves, it is possible to identify where specific articles from the UNCRC and the Universal Declaration on Human Rights (UDHR) might be seen within the dialogue. While allowing the participants to explore issues within the articles, it also affords the teacher a jumping-off point to explore further the children's learning about human rights, thereby directly impacting on their learning for human rights. For example, the dialogue relates to Article 1 of the UDHR, and Article 2 of the UNCRC is clearly seen earlier in the dialogue, though only alluded to in the transcript shown, when the participants discuss homophobic bullying and discrimination on grounds of one's gender and sexual preference. Importantly, in undertaking the dialogue they are, in effect, addressing Articles 12,13 and 14 of the UNCRC and Articles 18 and 19 of the UDHR. Article 23 of the UDHR focuses on rights related to work and equal pay; the dialogue shows that this is an issue for the children, that the notion of equal or fair pay is something that demands scrutiny. Indeed, they do not focus simply on their own lives or their own country or continent but make a connection to Africa. Teachers must be cautious of making human rights seem like a problem that is a geographically distant one (Chamberlain, 2001; Bromley, 2011), but the children in this dialogue make a link to those in another continent and use this to develop their argument around fairness and equality rather than seeing the issue at hand as one belonging to another place and people. Indeed, they recognise the rights issue by comparing different contexts to make clear the inequitable situation as some of them see it, thereby allowing for contextual information and understanding that Struthers (2015) sees as vital in teaching human rights.

\section{Conclusion}


Creating the space that Lundy (2007) refers to is vital in taking a human rights-based approach to deliberative participation. Scope must be given where ideas can be exchanged and explored freely without pressure of assessment, in other words, without someone else's agenda being imposed on the dialogue - and, therefore, its participants. By owning the dialogue the children are engaged in an open, attentive, respectful, questioning, reasoning, thoughtful and considered discussion. They are learning through rights, by adopting the CoPI rules to support their inquiry. At the same time, they are learning for rights by engaging in an approach that supports them in their engagement with others and in surfacing topics and questions that impact on their lives and the lives of people around them. The teacher can use the content of the dialogues as a stimulus for teaching specific pieces of information or particular skills that might be required in learning about rights, where the overlap between concepts and processes might usefully be addressed such as in the example above where it is clear that input is required to support the children in their understanding of democracy. This then supports the children to probe deeper into the systems and ideas related to democracy in future dialogues. The power imbalance from other teacher-pupil activities (Robinson, 2011) is addressed in CoPI, ensuring that children have ownership of the dialogue and the ideas therein but that the teacher can also be more responsive in her planning with the children directing the focus for that learning since the teacher can use the dialogue to assess children's understanding of core ideas.

What is proposed here is that approaches such as CoPI might be a useful model for thinking about how best to progress and facilitate children's engagement in and with rights. In the twenty-five years of the International Journal of Children's Rights the importance of children's rights has been stressed, the need for children's participation and engagement has been asserted, and in moving through the next twenty-five years what is needed is an approach that enables children to speak for themselves in a manner that is more than seeking their views when being consulted. Dialogic participation, through approaches such as CoPI, supports children: to raise issues they deem to be important; to challenge ideas; to make connections between what they have experienced through reading, viewing or at first hand; to think for themselves; and to offer agreement and also 
disagreement with others in a safe space. Importantly, it enables them to practise human rights behaviour as a means of participating beyond consultation exercises. Further, it facilitates their engagement with ideas and issues that are important to the promotion of rights for all.

\section{References}

Bartels, R., Onstenk, J. and Veugelers, W.,"Philosophy for Democracy”, Compare: A Journal of Comparative and International Education 2016 (46(5)), 681-700, DOI:

$10.1080 / 03057925.2015 .1041367$

Biesta, G., Lawy, R. and Kelly, N., “Understanding Young People's Citizenship Learning in Everyday Life: The Role of Contexts, Relationships and Dispositions", Education, Citizenship and Social Justice 2009 ((4)5), 5-24. DOI: 10.1177/1746197908099374.

Bromley, P., "Multiculturalism and Human Rights in Civic Education: the Case of British Columbia, Canada", Educational Research 2011 (53(2)), 151-164. DOI: 10.1080/00131881.2011.572363.

Bron, J. and Thijs, A., "Leaving it to Schools: Citizenship, Diversity and Human Rights Education in the Netherlands", Educational Research 2011 (53(2)), 123-136. DOI: 10.1080/00131881.2011.572361.

Chamberlain, M., "Human Rights Education for Nursing Students", Nursing Ethics 2001 (8(3)), 211222.

Cassidy, C., Thinking Children (London: Continuum, 2007).

Cassidy, C. (2012a). Philosophy with Children: learning to live well. Childhood \& Philosophy 8(16), 243-264.

Cassidy, C. (2012b). Questioning Children. Thinking: the Journal of Philosophy for Children 20 (1\&2), $62-68$ 
Cassidy, C. (2016). Promoting human rights through Philosophy with Children. International Journal of Children's Rights 24(3), 499-521.

Cassidy, C. and Christie, D. (2014). Community of Philosophical Inquiry: citizenship in the classroom. Childhood \& Philosophy 10(19), 33-54.

Cassidy, C., Christie, D., Marwick, H., Deeney, L., McLean, G, Rogers, K. (under review). Fostering citizenship in marginalised children through participation in Community of Philosophical Inquiry. Gazzard, A., "Philosophy for Children and the Discipline of Philosophy", Thinking: the Journal of Philosophy for Children 1996 (12(4)), 9-16.

Gregg, B., The Human Rights State. Justice Within and Beyond Sovereign Nations. (Philadelphia: Pennsylvania University Press, 2016).

Gündoğu, K. and Yildirim, A., "Voices of Home and School on Democracy and Human Rights Education at the Primary Level: a Case Study", Asia Pacific Education Review 2010 (11(4)), 525-532. DOI: 10.1007/s12564-010-9098-9.

Lipman, M., Thinking in Education (2 ${ }^{\text {nd }}$ edition). (Cambridge, Mass.: Cambridge University Press, 2003).

Lundy, L., "'Voice' is not Enough: Conceptualising Article 12 of the United Nations Convention on the Rights of the Child", British Educational Research Journal 2007 (33(6)), 927-942. DOI: 10.1080/01411920701657033.

Lunenberg, M. and Korthagen, F., "Experience, Theory, and Practical Wisdom in Teaching and Teacher Education", Teachers and Teaching: Theory and Practice 2009 (15(2)), 225-240. DOI: $10.1080 / 13540600902875316$

MacNaughton, G., Hughes, P. and Smith, K., "Early Childhood Professionals and Children's Rights: Tensions and Possibilities Around the United Nations General Comment No. 7 on Children's Rights", 
International Journal of Early Years Education 2007 (15(2)), 161-170. DOI:

10.1080/09669760701288716.

McCall, C., Stevenson Lectures on Citizenship. (Glasgow: University of Glasgow Press, 1991).

McCall, C., Transforming Thinking. Philosophical Inquiry in the Primary and Secondary Classroom. (London: Routledge, 2009).

Murris, K., "Can Children do Philosophy?", Journal of Philosophy of Education 2000 ((34)2), 261-279. DOI: 10.1111/1467-9752.00172.

Robinson, C., "Children's Rights in Student Voice Projects: Where Does the Power Lie?", Education Inquiry 2011 (2(3)), 437-451. DOI: 10.3402/edui.v2i3.21993.

Schertz, M., "Avoiding 'passive empathy' with Philosophy for Children", Journal of Moral Education 2007 (36(2)), 185-198. DOI: 10.1080/03057240701325308.

Shultz, L. and Guimaraes-losif, R., "Citizenship Education and the Promise of Democracy: A Study of UNESCO Associated Schools in Brazil and Canada", Education, Citizenship and Social Justice 2012 (7(3)), 241-254. DOI: 10.1177/1746197912448712.

Struthers, A.E.C., "Human Rights Education: Educating About, Through and For Human Rights", The International Journal of Human Rights 2015 (19(1)). DOI: 10.1080/13642987.2014.986652.

United Nations. United Nations Convention on the Rights of the Child. (Geneva: United Nations, 1989).

Westheimer, J. and Kahne, J., "What Kind of Citizen? The Politics of Educating for Democracy", American Educational Research Journal 2004 (41(2)), 237-269. 